\title{
The Role of Immune Checkpoint Inhibitors in Classical Hodgkin Lymphoma
}

\author{
Nicholas Meti ${ }^{(D)}$, Khashayar Esfahani and Nathalie A. Johnson * \\ Department of Medicine, Jewish General Hospital, McGill University, Montreal, QC H3T 1E2, Canada; \\ nicholas.meti@mail.mcgill.ca (N.M.); khashayar.esfahani@mail.mcgill.ca (K.E.) \\ * Correspondence: Nathalie.johnson@mcgill.ca; Tel.: +1-514-340-8222 (ext. 28434)
}

Received: 16 May 2018; Accepted: 12 June 2018; Published: 15 June 2018

\begin{abstract}
Hodgkin Lymphoma (HL) is a unique disease entity both in its pathology and the young patient population that it primarily affects. Although cure rates are high, survivorship can be linked with significant long-term morbidity associated with both chemotherapy and radiotherapy. The most significant recent advances have been with the use of the anti-CD30-drug conjugated antibody brentuximab vedotin (BV) and inhibitors of program death 1 (PD-1). HL is genetically wired to up-regulate program death ligand 1 (PD-L1) in $>95 \%$ of cases, creating a state of so-called "T cell exhaustion", which can be reversed with immune checkpoint-inhibitor blockade. The overall and complete response rates to PD-1 inhibitors in patients with relapsed or refractory HL are $70 \%$ and $20 \%$, respectively, with a long median duration of response of $\sim 16$ months. In fact, PD-1 inhibitors can benefit a wide spectrum of relapsed HL patients, including some who have "progressive disease" by strict response criteria. We review the biology of HL, with a focus on the immune micro-environment and mechanisms of immune evasion. We also provide the rationale supporting the use of PD-1 inhibitors in HL and highlight some of the challenges of monitoring disease response in patients treated with this immunotherapy.
\end{abstract}

Keywords: Hodgkin Lymphoma; immune checkpoint inhibitors; immunotherapy

\section{Overview of Hodgkin Lymphoma}

Hodgkin Lymphoma (HL) has an annual incidence of 2-3 cases per 100,000 in Europe and the USA, and epidemiological data has revealed that one in eight patients will die from the disease [1-3]. It has a bimodal peak, with young adults aged between 15-34 being the most affected, followed by those aged 60 and older [4]. Although the cause of HL is unknown, several risk factors have been studied. These include genetic predisposition [5], immunosuppression in the context of human immunodeficiency virus infection [6], and other viral infections such as Epstein Barr Virus [7]. Based on cellular morphology and immunohistochemistry, HL can be classified into either classical HL (cHL) or nodular lymphocyte-predominant HL (NLPHL) [8-10]. cHL represents approximately 90\% of all HL and can be further classified into four histological subtypes known as nodular sclerosis HL, mixed cellularity HL, lymphocyte-rich HL, and lymphocyte depleted HL. Given the predominance of cHL, this review will focus on $\mathrm{cHL}$ and advancements in the treatment of cHL.

\section{Biology and Diagnosis of Classical Hodgkin Lymphoma}

The histological presence of mononuclear Hodgkin $(\mathrm{H})$ and bi- to multi-nuclear, diagnostic Reed-Sternberg (RS) cells is pathognomonic of cHL. Given that both cell types are malignant, they are also referred to as HRS cells. They are derived from clonal germinal center B (GCB) cells, having rearranged and mutated immunoglobulin variable genes [11], However, with the 
exception of PAX5, typical GCB surface markers (CD19, CD79) and transcription factors (OCT-2, BOB.1 and PU.1) are down-regulated or completely absent in HRS cells and CD20 is expressed in only $20 \%$ of cases $[10,12,13]$. In contrast, HRS cells universally express CD30 and $75-85 \%$ of cases express CD15 [14-21]. The reprogramming and loss of the B cell phenotype in HRS cells likely occurs due to genomic alterations that alter important signaling pathways, including NOTCH-1, Janus kinase and Signal Transducer and Activator of Transcription (JAK/STAT), and nuclear factor kappa B (NF-kB) [22-24]. Genomic amplification of REL, MAP3K14, and BCL3 and mutations in NFKBIE, NFKBIA, and TNFAIP3 contribute to constitutive activation of the NF- $\mathrm{kB}$ pathway, promoting the survival of HRS cells [23,25-29]. Constitutive JAK/STAT signaling is also a hallmark of cHL and most commonly occurs as a consequence of amplification of JAK2 and mutations in STAT6 [30-32]. More recently, whole exome sequencing of HRS cells has revealed that $~ 90 \%$ of cHLs harbor mutations affecting the JAK/STAT pathway (including STAT6, SOCS1, STAT3, STAT5B, JAK1, $J A K 2$, and PTPN1) [33]. Other genomic alterations also contribute to HRS survival by implicating the nuclear export of proteins and RNAs (XPO1), AKT signaling (GNA13 and ITPKB), and evasion of immune surveillance (CIITA, PDL1, B2M, CD58, and TNFRSF14) [33]. Finally, HRS cells have genomic instability resulting from ongoing chromosomal rearrangements [34] and disruption of 3D telomere-TRF2 interaction [35].

The HRS cell represents only $\sim 1 \%$ of all cells within the tumor environment, the remaining being composed of various immune cells, such as macrophages, eosinophils, neutrophils, mast cells, fibroblasts, and B and T lymphocytes. The predominant fraction of these immune cells belong to the CD4+ T cell family, specifically T helper 2 (Th2) and T regulatory (Treg) cells [36-38]. These immune cells are recruited to this inflammatory milieu by the presence of cytokines and chemokines within the microenvironment. In fact, HRS cells can express and secrete CCL5, CCL17, CCL22, and IL-5, all of which can attract CD4+ T cells into the microenvironment [39]. Once the CD4+ T cells rosette the HRS cells, various ligand-receptor interactions occur, including CD40-CD40L, which has been shown to trigger the NF-KB pathway and lead to further production and maintenance of HRS cell colonies [40-43].

In order to thrive in a lymphocyte-rich microenvironment, HRS cells have developed multiple mechanisms to promote immune tolerance. The most clinically significant mechanism of dampening effector $\mathrm{T}$ cell function is by stimulating the programmed death 1 (PD-1)/programmed death ligand 1 (PD-L1) immune checkpoint. PD-L1 expression is variable in cHL patients [44,45], but recent evidence has demonstrated that the level of expression of PD-L1 is associated with the number of copies of the PDL1 gene locus present on chromosome arm 9p24. High-level amplification, present in a third of HL cases, is associated with the highest expression of PD-L1 protein at the cell surface [46]. The 9p24.1 amplification also contains Janus kinase 2 (JAK2) and PDL2, which further upregulates PD-L1 expression, the former through activation of JAK/STAT signaling [46]. Finally, Epstein-Barr virus (EBV), present in HRS in 30-40\% of classical HL, can also promote the expression of PD-L1 and PD-L2 [47]. More specifically, EBV induces PD-L1 expression through the activation of the transcription factor pathway AP1 and downstream upregulation of c-Jun and JunB, a hallmark pathway of classical HL, irrespective of 9p24.1 copy numbers $[48,49]$. In addition to hijacking the immune checkpoint system, HRS cells have also evolved other mechanisms to evade immune surveillance. Recent evidence is emerging that highlights a lack of $\beta_{2}$-microglobulin (B2M) and Major Histocompatibility Complex (MHC) class I at the HRS cell surface in $~ 90 \%$ of cHL cases, which is an essential requirement for an effective CD8+ T cell cytotoxic response [50-52]. Furthermore, MHC class II is not expressed on the surface of HRS in $\sim 40 \%$ of cHL cases, which is critical for antigen presentation to CD4+ helper T cells [53]. Taken together, HRS cells have adapted multiple mechanisms to evade immune surveillance and thrive in an immune rich milieu (Figure 1). 


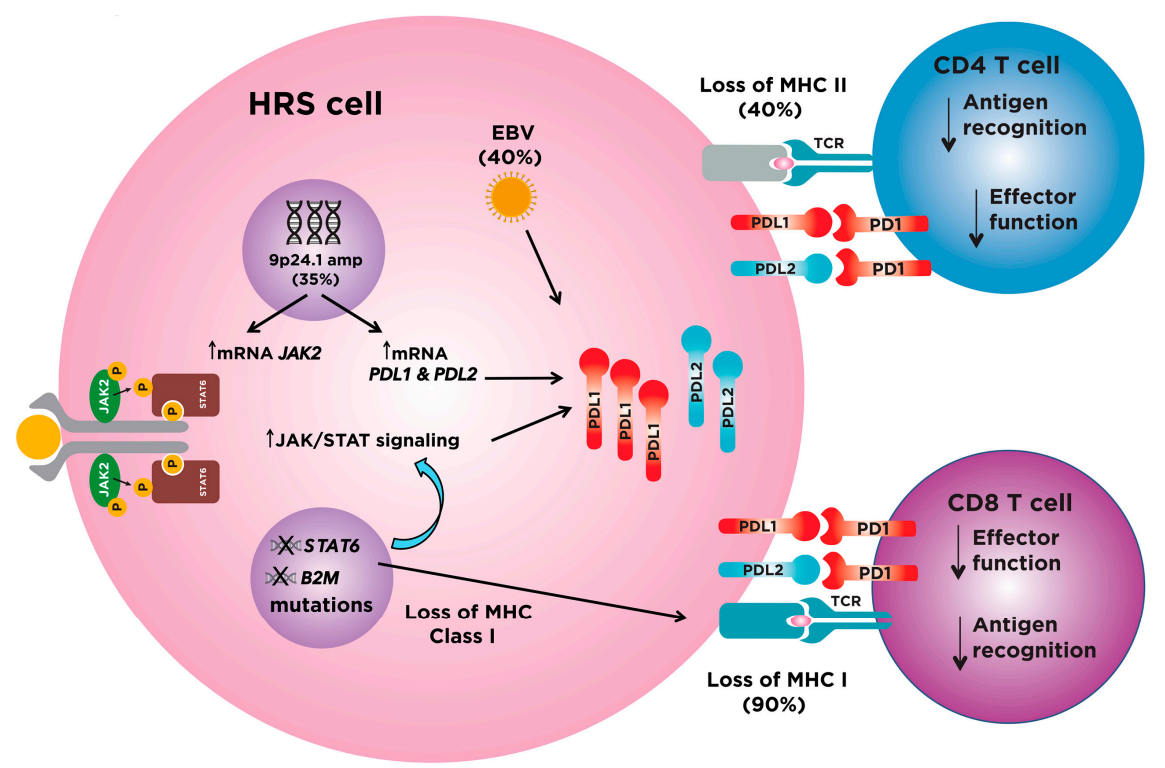

Figure 1. Hodgkin Reed-Sternberg (HRS) cells escape immune detection by over-expressing program death ligands PDL1/PDL2 and silencing Major Histocompatibility Complex (MHC) expression. HRS cells over-express PDL1 and PDL2, both ligands for PD1 on T cells, which once engaged, suppresses $\mathrm{T}$ cell effector function. The main mechanisms of over-expression are amplification of 9p24.1, the location of PDL1, PDL2 and Janus kinase 2 (JAK2). Over 90\% of classical Hodgkin Lymphomas (cHLs) harbor genetic alterations that may activate JAK/STAT signaling, the most common being JAK2 and STAT6, which can ultimately increase PDL1 expression. Epstein-Bar Virus (EBV) can further increase the expression of PDL1 and PDL2. HRS cells can also promote immune tolerance by silencing the expression of MHC class I and II molecules, which are key to present tumor antigens and activate CD8 and CD4 T cells, respectively. Abbreviations: HRS, Hodgkin Reed-Sternberg; PDL1, program death ligand 1; PDL2, program death ligand 2; PD1, program death 1; MHC I, major histocompatibility complex class I; MHC II, major histocompatibility complex class II; B2M, beta 2 microglobulin, a component of MHC I.

\section{Management of Classical Hodgkin Lymphoma}

The initial management of cHL is based on the patient's stage and presence of adverse factors at the time of diagnosis. Positron emission tomography and contrast-enhanced computed tomography (PET/CT) is recommended for initial staging and for subsequent assessment of response to treatment [54]. Chemotherapy remains the standard initial treatment of limited and advanced stage cHL, but the preferred regimen, the number of cycles administered, and the addition of radiation therapy is a matter of debate, which has already been featured in recent reviews [55-57]. The two main chemotherapy regimens include either (1) adriamycin (A), bleomycin (B), vinblastine (V), and dacarbazine (D) (ABVD) or (2) bleomycin, etoposide, adriamycin, cyclophosphamide, vincristine, procarbazine, and prednisone (BEACOPP). The two main treatment options for patients with limited stage cHL are either a standard abbreviated course of chemotherapy, typically ABVD, followed by involved field radiation therapy (IFRT) [58,59] or 4-6 cycles of chemotherapy in patients who are deemed not candidates for radiotherapy [60], or a risk-adapted strategy based on the results of an interim PET (iPET) scan performed after 2-3 cycles of ABVD [61,62]. Approximately 80\% of patients will be classified as low-risk (iPET-negative), and chemotherapy alone (total 3-4 cycles) without radiation could be considered at a cost of $\sim 5 \%$ increased risk of relapse [61]. Combined modality therapy, with possible escalation to BEACOPP, can be considered for the remaining high-risk patients with iPET-positive scans [62]. Patients with advanced stage disease are managed with chemotherapy, either ABVD or BEACOPP, or can follow a risk-adapted approach in which patients are given 2 
cycles of ABVD, and, if the iPET is negative, bleomycin can be omitted from the subsequent cycles and if the iPET scan is possible, one can consider escalation to BEACOPP $[63,64]$. The United States Federal Drug Administration (USFDA) recently approved the addition of brentuximab vedotin (BV) to AVD as an alternative front-line option for patients with advanced HL. BV is an anti-CD30 antibody conjugated monomethyl auristatin E (MMAE) that has significant activity in the relapse setting. In the ECHELON-1 trial, which included 1334 patients with untreated stage III or IV cHL, BV + AVD (AAVD) had a $5 \% 2$ year modified progression-free survival (PFS) advantage over ABVD, but was associated with increased rates of neutropenia and neuropathy [65]. In this trial, 67/1334 (5\%) of patients died, with over $90 \%$ of events due to treatment-related toxicity, febrile neutropenia in patients treated in the AAVD arm and bleomycin-lung toxicity in the ABVD arm.

The management of patients with relapsed and refractory classical Hodgkin lymphoma (rrHL) that has progressed after frontline therapy is to proceed with salvage chemotherapy followed by autologous stem cell transplant (ASCT) in eligible patients [66]. Multiple salvage chemotherapy regimens have been tested in this setting, but none have been shown to improve overall survival over another [67]. Consolidation with an ASCT in patients with chemo-sensitive disease is considered curative in $\sim 50 \%$ of cases $[66,68-70]$. One drug that has been extremely effective in rHL is BV due to the hallmark feature of increased CD30 expression. The unconjugated anti-CD30 antibody, without MMAE, had minimal clinical activity in patients with rrHL, having an overall response rate (ORR) of $0 \%$ [71]. Based on these data, one can conclude that the main clinical benefit of BV is not a consequence of immune-mediated cytotoxicity, but rather the delivery of a potent anti-microtubule inhibitor to HRS cells [71,72]. In patients with rrHL that has relapsed after ASCT, BV has an ORR of $75 \%$ and a complete response (CR) rate of $34 \%$. The 5-year PFS and overall survival (OS) was $22 \%$ and $41 \%$, respectively [72,73]. Given the impressive response rates of BV in this setting, it has been studied in combination with chemotherapy as part of salvage therapies. For example, BV combined with bendamustine demonstrated impressive results in 2 recent phase I-II trials, with an ORR of 78-93\% and CR rate of $43-77 \%[74,75]$. In the study by LaCasce et al., $56 \%$ of patients treated with BV and bendamustine experienced infusion-related reactions (IRR) events, which were found to be associated with the production of anti-BV antibodies after cycle 1 in $75 \%$ of their patients [75]. BV maintenance can also extend the duration of remission in high-risk patients post ASCT. In the AETHERA phase III trial, maintenance BV extended PFS by 19 months compared to observation alone [76]. There was no overall survival benefit with this strategy and the main toxicities were neutropenia and sensory peripheral neuropathy, which were reversible in most patients.

Taken together, the general approach in treating cHL patients has been to select a treatment that will maximize cure (OS) and minimize long-term toxicity. Unfortunately, these end-points are not often reported in clinical trials due to the extended follow-up time required to capture them. Adding a therapy that has no or very little long-term toxicity to the initial chemotherapy backbone has the potential to improve the outcome of patients with cHL by limiting exposure to subsequent therapy and ASCT that can increase long-term morbidity.

\section{Immune Checkpoint Inhibitors in Classical Hodgkin Lymphoma}

In the past decade, there has been a tremendous success in the field of cancer immunotherapy with the introduction of immune checkpoint inhibitors (ICI). Following exposure to antigen and T cell activation, immune checkpoints (ICs) become expressed at the surface of $\mathrm{T}$ cells to inhibit $\mathrm{T}$ cell function [77]. This innate mechanism of avoiding damage to self upon chronic antigen exposure is often hijacked by tumors to escape immune detection. The most clinically-relevant IC in cHL is PD-1. PD-L1 expression is not only seen on HRS cells but also on tumor-associated macrophages (TAMs), which may further contribute to so-called T cell exhaustion [44,78]. Engaging PD-1/PD-L1 impairs antitumor $\mathrm{T}$ cell function by inhibiting downstream signaling from co-stimulatory receptors and by inducing direct transcription of genes known to suppress T cell function [79]. In addition to PD-1, other ICs are can be expressed at the surface of T cells (e.g., CTLA-4, LAG-3, TIM3, 2B4, CD160, 
BTLA, and CD112R/TIGIT), further mitigating T cell functions and enforcing T cell exhaustion [79-81]. The first ICI to be approved by the USFDA was the anti-CTLA- 4 inhibitor ipilimumab for the treatment of melanoma [82]. Upregulation of CTLA-4 on the T-cell competes for the co-stimulatory receptor CD28 thus inhibiting its interaction with B7, thereby inhibiting T-cell activation [83]. In solid tumors, PD-1/PD-L1 engagement occurs in the peripheral tumor micro-environment, whereas the CTLA-4/B7 interaction occurs in the lymph node. This distinction in lymphoma is less clear. In both animal models and pharmacological studies, $\mathrm{T}$ cell exhaustion has been shown to be a reversible process with ICI inhibitors $[84,85]$, suggesting it is an effective strategy to restore effector T cell function and cell-mediated cytotoxicity.

Given that cHL is genetically programmed to over-express PD-L1, the first clinical trials were with the PD-1 inhibitors nivolumab and pembrolizumab. Nivolumab was evaluated in a Phase I study (CHECKMATE 039) of 23 patients with rrHL who were heavily pre-treated with systemic therapy, including ASCT in most patients [86]. It had an ORR of $87 \%$ and a CR of $17 \%$. Pembrolizumab (KEYNOTE 013) was tested in 31 heavily pre-treated rrHL patients and demonstrated an ORR of $65 \%$ with a CR of $16 \%$ [87]. Given these encouraging preliminary results, two subsequent phase 2 trials (CHECKMATE 205 and KEYNOTE 087) were designed to further evaluate the clinical efficacy of these PD-1 inhibitors. Both trials evaluated the clinical activity of nivolumab and pembrolizumab in separate cohorts, thus representing the full spectrum of rrHL patients with varying degrees of previous treatment with BV and ASCT [88-90]. All cohorts demonstrated a similar response to nivolumab and pembrolizumab, revealing that, regardless of previous treatment history, patients with rrHL retained PD-1 sensitivity and vulnerability. Overall, $70 \%$ of patients with rrHL respond to PD-1 inhibitors and $20 \%$ have complete responses. The duration of response may be longer with PD-1 inhibitors compared to BV. This hypothesis is being tested in the ongoing Keynote 204 study that randomizes rrHL to receive either BV or pembrolizumab (NCT02684292). In the CHECKMATE 205 study, the median duration of response and PFS to nivolumab was 17 months and 15 months, respectively, which compares favorably to the median PFS of 6 months in patients treated with BV $[72,90]$. The benefit of nivolumab was not restricted to patients achieving a CR or Partial Response (PR), because even patients with stable disease had a PFS that exceeded 11 months. At a median follow up time of 18 months, the median OS of all patients, including those with "progressive disease", had not been reached, supporting that PD-1 inhibitors are very beneficial in chemo-refractory HL. As monotherapy, they are also very well-tolerated, with only $\sim 5 \%$ of patients experiencing severe adverse events [90]. PD-L1 inhibitors are also active in rrHL. In the phase I JAVELIN Hodgkin trial (NCT02603419), the PD-L1 inhibitor avelumab had an ORR of $55 \%$ and CR of $7 \%$, further demonstrating that inhibiting the PD-1/PD-L1 axis is effective in HL [91]. A summary of these trials is presented in Table 1.

Table 1. Summary of clinical trial data for anti-PD-1 (program death 1) monotherapy, combination immune checkpoint inhibitors (ICI), and ICI + brentuximab vedotin (BV) in cHL patients (classical Hodgkin Lymphoma).

\begin{tabular}{|c|c|c|c|c|}
\hline Drug & Phase & ORR\% & CR\% & Ref. \\
\hline \multicolumn{5}{|c|}{ Monotherapy } \\
\hline Nivolumab & I & 87 & 17 & [86] \\
\hline Nivolumab & II & 68 & 9 & [92] \\
\hline Pembrolizumab & $\mathrm{I}$ & 65 & 16 & [87] \\
\hline Pembrolizumab & II & 69 & 22 & [88] \\
\hline Avelumab & $\mathrm{I}$ & 54.8 & 6.5 & [91] \\
\hline \multicolumn{5}{|c|}{ Combination Therapy } \\
\hline Nivolumab + Ipilimumab & I & 74 & 19 & [93] \\
\hline Nivolumab + Brentuximab Vedotin & $\mathrm{I} / \mathrm{II}$ & 82 & 61 & [94] \\
\hline Ipilimumab + Brentuximab Vedotin & $\mathrm{I} / \mathrm{II}$ & 72 & 50 & [95] \\
\hline Nivolumab + AVD & II & 84 & 67 & [96] \\
\hline
\end{tabular}


Following the impressive results with PD-1 inhibitors as monotherapy, nivolumab was tested in combination with other therapies (Table 1). In the CHECKMATE 039 trial, 31 patients with rrHL received combination nivolumab and ipilimumab. The ORR was $74 \%$ and the CR was $19 \%$, which is a similar response achieved with PD-1 blockade alone, suggesting that CTLA-4 inhibition is not the best strategy to improve response rates to PD-1 inhibition. Moreover, patients treated with this combination of ICI experienced more frequent grade 3 immune-related adverse events (irAEs). The combination of nivolumab and BV was conducted in rrHL patients at first relapse, after having failed frontline therapy $[94,97]$. The ORR of BV and nivolumab was similar to nivolumab alone $(82 \%)$, but CR rate was significantly higher (61\%), and the PFS at 6 months was 91\% [94]. Interestingly, $44 \%$ of patients had grade 1-2 IRR, which are uncommon with either agent alone. The explanation for these adverse IRRs was unclear, but the authors speculated that given the patients are in the first salvage setting, they may have had an enhanced ability to mount an immune response. BV decreased peripheral CD30+ cells and increased pro-inflammatory cytokines and nivolumab increased the number of circulating $\mathrm{T}$ cells, suggesting that BV primes the tumor environment for effective immune infiltration and attack. The safety and efficacy of the combination of nivolumab and AVD in 51 patients with untreated advanced stage cHL or high-risk stage II cHL was recently reported in abstract form [96]. These patients received 4 bi-weekly doses of nivolumab monotherapy followed by nivolumab in combination with AVD. The safety profile of this regimen was similar and consistent with the use of either nivolumab or AVD separately, raising no concerns. With limited follow-up time, the ORR was $84 \%$ and the CR rate was $67 \%$. Taken together, PD-1 inhibitors can be safely combined with other therapeutic agents in cHL. Additional work will inform us on the best timing of therapy and the best partner to maximize efficacy without compromising safety.

\section{Evaluating Response to Immune Checkpoint Inhibitors in Classical Hodgkin Lymphoma}

Although the current standard of monitoring disease activity in cHL patients relies on PET/CT [98], limited recommendations exist to guide clinicians in their evaluation of response to ICI. In general, response to therapy has been evaluated using the 2007 [98] and 2014 [99] Revised Response Criteria for Malignant Lymphomas. Although these criteria have been validated in both standard of care and clinical trial populations, they were developed prior to the introduction of ICI therapy. With an increasing number and type of immunotherapy agents under use, an updated criterion labeled as "indeterminate response" was proposed in 2016 to help clinicians in the setting of a common problem encountered with ICIs: "pseudoprogression" [100]. The latter refers to the phenomena of an increased tumor size on imaging or new "lesions", which might mimic tumor progression by increased tumor bed infiltration by immune cells secondary to immune activation. In the context of lymphoma, this may also occur with immune activation from other causes, such as infections. In this setting, anti-PD-1 therapy can be continued beyond progression of disease (PD) if the patient appears to be deriving clinical benefit, has a good performance status, and has a non-rapid "progression". Subsequent follow-up imaging or biopsy is required to confirm PD. This approach is deemed safe based on the outcome data collected on 70/243 patients, with rrHL patients treated "beyond progression" on the CHECKMATE 205 trial [90]. The most common reason for reporting PD was the presence of new lesions in $67 \%$ of patients. Continued treatment with nivolumab in this setting resulted in the overall reduction in tumor burden in many patients. The median time to next treatment was 17 months and the overall survival for patients treated beyond progression was $84 \%$ at 1 year versus $64 \%$ in patients who stopped treatment [90]. Thus, improved modalities are clearly needed to evaluate treatment responses in lymphoma patients treated with ICI.

\section{Biomarkers of Response to Immune Checkpoint Blockade in Classical Hodgkin Lymphoma}

In immune-oncology, cHL is the tumor that has the highest response to PD-1 inhibitors. This is likely due to the high expression of PD-L1 due to copy number gains of 9p24.1. A strong intensity of PD-L1 protein expression and amplification of 9p24.1 can be considered as predictive 
biomarkers of a favorable response to PD-1 inhibitors. This is in contrast to patients with lung cancer, where clinical responses to PD-1 inhibitors can occur irrespective of PD-L1 expression on the tumor cells [101]. Interestingly, amplification of 9p24.1 is also a predictive biomarker of a poor response to conventional chemotherapy. Supporting this finding is that patients with primary refractory $\mathrm{cHL}$ in the KEYNOTE-087 study had responses to pembrolizumab that were comparable to the overall rrHL population [102]. In solid tumors, PD-1 inhibitors eliciting a CD8+ mediated cytotoxicity and neoantigen exposure from increased mutation burden is a predictive marker of response [103,104]. However, CD8+ T cells require MHC class I engagement for the cytocidal effect and the latter is lost in $>90 \%$ of HRS cells. This was confirmed in a recent analysis of biopsies obtained from CHECKMATE 205, where 11/12 responses to nivolumab occurred in patients that lacked MHC class I protein, but expressed MHC class II [105]. Patients with HRS cells harboring amplifications 9p24.1 and express MHC class II on their surface had the highest probability of responding to nivolumab. This study suggests that CD4+ T cells, via an alternative MHC class II-dependent mechanism, play a key role in the response of PD1 blockade therapy.

Other factors, such as elevated leukocyte and eosinophil counts, have been associated with increased risk of progression when treated on PD-1 inhibitors, whereas a lower relative eosinophil count was associated with a reduced risk of progression [106,107].

\section{Future Directions in the Management of Classical Hodgkin Lymphoma}

PD-1 inhibitors are clearly active in rrHL, but there are many unanswered questions regarding the optimal duration and timing of therapy, as well as the best adjuvant therapies that can be safely combined with them to improve efficacy. In patients achieving a CR with PD-1 inhibitors, can therapy be stopped and, if yes, after how many cycles? Two recent studies have reported that a subset of patients who discontinue PD-1 inhibitors while in CR can have long-lasting remissions without relapse beyond a year of follow up $[90,108]$. If the disease relapses after discontinuing therapy while in CR, is retreatment with PD-1 inhibitors effective? Long-term follow-up of rrHL patients who have remained in CR after discontinuing therapy will provide insight into these issues. Although PD-1 inhibitors are currently approved in cHL patients in the relapse setting, ongoing trials are evaluating them earlier in the course of the disease, e.g., as a pre-transplant salvage regimen or as part of the initial induction therapy. Thus, the best timing to initiate anti-PD-1 therapy and the best combination therapy is an open question.

Treatment regimens that provide good tumor control with limited short and long-term toxicities are needed in HL, especially in older patients that do not tolerate chemotherapy [109-111]. Evaluating regimens that include drugs that do not suppress effector immune function seems logical, e.g., drugs that directly target the HRS cell or its micro-environment. Antibody-drug conjugates have the advantage of delivering chemotherapy directly to the tumor cells while decreasing toxicity to immune cells and other tissues. An obvious example of this would be to test BV and a PD-1 inhibitor as a front-line regimen in elderly patients, given that HRS cells appear vulnerable to microtubule inhibition. Radiation has also been safely combined with ICI therapy and may be beneficial in older patients that are less likely to develop the long-term toxicity of radiation. Radiation has been shown to augment response to ICIs, known as the abscopal effect [112]. This phenomenon occurs when targeted radiotherapy to one site leads to disease response in other, non-radiated areas. It has been previously described in other types of cancer [113,114], and is being formally evaluated in cHL (clinical trial NCT03179917). Table 2 summarizes selected ongoing clinical trials testing combination therapy with ICI in cHL (a more comprehensive list can be found in a recent review [115]).

Another area of research is to understand the mechanisms and risk factors that contribute to developing immune-related adverse events (irAEs). Although generally well tolerated, $\sim 5 \%$ of cHL patients experience severe, grade 3-4 irAEs to PD-1 inhibitors. There is currently no biomarker or risk factor that can predict which patients are at risk of developing these events. There is also little data on the safety of re-treating patients after an irAE when there is a good anti-tumor response. Patients with 
auto-immune diseases have been excluded from most ICI trials. However, in the "real world" setting, such patients have been treated with PD-1 inhibitors to treat solid tumors without developing irAEs or "auto-immune flares".

Given that treatment with PD-1 inhibitors "beyond progression" has benefited many cHL patients, there is an urgent need to improve the modalities used to monitor tumor burden in these patients. An exciting and novel method in cHL currently under investigation is the analysis of circulating tumor DNA (ctDNA). Using deep sequencing technology, ctDNA can be detectable in the plasma of patients with de novo cHL and also rrHL [116]. Moving forward, this may be used to risk stratify patients at diagnosis and follow their response in a longitudinal, non-invasive manner. This would also spare patients from recurrent radiation exposure incurred through multiple CT/PET scans. In addition to ctDNA, other biomarkers, such as serum TARC, Galectin-1, and CD163 have been highlighted as potential biomarkers of disease response [29]. These new technological advances may offer clinicians more sensitive tools to monitor $\mathrm{cHL}$ tumor burden that transcends the current radiological approach.

Table 2. Summary of all ongoing trials using immune checkpoint inhibitors in combination with other agents in rrHL as of March 1st, 2018. BV = Brentuximab Vedotin; ICE = Ifosfamide, Carboplatin, and Etoposide; ISRT = Involved site radiation therapy.

\begin{tabular}{ccc}
\hline Combination ICI Clinical Trials & Phase & Trial ID \\
\hline Nivolumab + Ipilimumab + BV & I & NCT01896999 \\
Nivolumab + Ipilimumab + Daratumumab & I & NCT01592370 \\
Nivolumab + Ipilimumab + Daratumumab + Pomalidomide & I & NCT01592370 \\
Nivolumab + Ibrutinib & II & NCT02940301 \\
Nivolumab + ICE chemotherapy & II & NCT03016871 \\
Pembrolizumab + ISRT & II & NCT03179917 \\
Pembrolizumab + AFM13 & I & NCT02665650 \\
Pembrolizumab + Lenalidomide & I/II & NCT02875067 \\
Pembrolizumab + ICE chemotherapy & II & NCT03077828 \\
Pembrolizumab + BV & III & NCT02684292 \\
Pembrolizumab + Vorinostat & I & NCT03150329 \\
Nivolumab + Bendamustine & I/II & NCT03343652 \\
\hline
\end{tabular}

\section{Conclusions}

The introduction and refinement of combined chemotherapy and radiotherapy over the last decades have cured most patients with primary cHL. Unfortunately, many of these patients die from treatment-related toxicity, underscoring the need to evaluate effective therapies that have fewer long-term toxicities, which will decrease the rates of secondary neoplasms and cardiac disease. The remarkable clinical activity of PD-1 inhibitors in HL is driven by the genetic reprogramming of HRS cells to evade immune surveillance through the PD-1/PD-L1 axis, with amplification of 9p24.1 and the presence of MCH class II being the most predictive positive biomarkers of response. While PD-1 inhibitors result in a slightly lower CR when compared to BV, the duration of response may be more durable. PD-1 inhibitors are especially effective in patients with primary refractory $\mathrm{CHL}$, suggesting that the immune-mediated cytotoxicity induced by PD-1 blockade is effective in killing chemotherapy-resistant cHL. Given their different mechanism of action and their favorable toxicity profile, PD-1 inhibitors have the potential to increase cures and, importantly, reduce the long-term treatment-related morbidity and mortality in patients with HL.

Author Contributions: N.M., K.E., and N.A.J. reviewed the articles and wrote the manuscript.

Funding: N.A.J. is supported by the Canadian Institute of Health Research (grant \#390686) and the Canadian Cancer Society (705478).

Acknowledgments: We thank Hans Knecht for his thoughtful comments in helping us revise this manuscript. 
Conflicts of Interest: Nathalie A. Johnson has received honoraria and has served as a consultant for Bristol Myers Squibb, Merck, Roche, and Abbvie.

\section{References}

1. Thomas, R.K.; Re, D.; Zander, T.; Wolf, J.; Diehl, V. Epidemiology and etiology of Hodgkin's lymphoma. Ann. Oncol. 2002, 13 (Suppl. S4), 147-152. [CrossRef] [PubMed]

2. Morton, L.M.; Wang, S.S.; Devesa, S.S.; Hartge, P.; Weisenburger, D.D.; Linet, M.S. Lymphoma incidence patterns by who subtype in the united states, 1992-2001. Blood 2006, 107, 265-276. [CrossRef] [PubMed]

3. Siegel, R.L.; Miller, K.D.; Jemal, A. Cancer statistics, 2017. CA Cancer J. Clin. 2017, 67, 7-30. [CrossRef] [PubMed]

4. Cartwright, R.A.; Watkins, G. Epidemiology of Hodgkin's disease: A review. Hematol. Oncol. 2004, 22, 11-26. [CrossRef] [PubMed]

5. Mack, T.M.; Cozen, W.; Shibata, D.K.; Weiss, L.M.; Nathwani, B.N.; Hernandez, A.M.; Taylor, C.R.; Hamilton, A.S.; Deapen, D.M.; Rappaport, E.B. Concordance for Hodgkin's disease in identical twins suggesting genetic susceptibility to the young-adult form of the disease. N. Engl. J. Med. 1995, 332, 413-418. [CrossRef] [PubMed]

6. Tirelli, U.; Errante, D.; Dolcetti, R.; Gloghini, A.; Serraino, D.; Vaccher, E.; Franceschi, S.; Boiocchi, M.; Carbone, A. Hodgkin's disease and human immunodeficiency virus infection: Clinicopathologic and virologic features of 114 patients from the Italian cooperative group on aids and tumors. J. Clin. Oncol. 1995, 13, 1758-1767. [CrossRef] [PubMed]

7. Alexander, F.E.; Jarrett, R.F.; Lawrence, D.; Armstrong, A.A.; Freeland, J.; Gokhale, D.A.; Kane, E.; Taylor, G.M.; Wright, D.H.; Cartwright, R.A. Risk factors for Hodgkin's disease by epstein-barr virus (EBV) status: Prior infection by EBV and other agents. Br. J. Cancer 2000, 82, 1117-1121. [CrossRef] [PubMed]

8. Harris, N.L.; Jaffe, E.S.; Stein, H.; Banks, P.M.; Chan, J.K.; Cleary, M.L.; Delsol, G.; De Wolf-Peeters, C.; Falini, B.; Gatter, K.C.; et al. A revised european-american classification of lymphoid neoplasms: A proposal from the international lymphoma study group. Blood 1994, 84, 1361-1392. [CrossRef]

9. Swerdlow, S.H.; Campo, E.; Pileri, S.A.; Harris, N.L.; Stein, H.; Siebert, R.; Advani, R.; Ghielmini, M.; Salles, G.A.; Zelenetz, A.D.; et al. The 2016 revision of the world health organization classification of lymphoid neoplasms. Blood 2016, 127, 2375-2390. [CrossRef] [PubMed]

10. Swerdlow, S.; Campo, E.; Harris, N.L.; Jaffe, E.S.; Pileri, S.A.; Stein, H.; Thiele, J.; Arber, D.A.; Hasserjian, R.P.; Le Beau, M.M.; et al. World Health Organization Classification of Tumours of Haematopoietic and Lymphoid Tissues, 4th ed.; International Agency for Research on Cancer (IARC): Lyon, France, 2017.

11. Kanzler, H.; Kuppers, R.; Hansmann, M.L.; Rajewsky, K. Hodgkin and Reed-Sternberg cells in Hodgkin's disease represent the outgrowth of a dominant tumor clone derived from (crippled) germinal center B cells. J. Exp. Med. 1996, 184, 1495-1505. [CrossRef] [PubMed]

12. Watanabe, K.; Yamashita, Y.; Nakayama, A.; Hasegawa, Y.; Kojima, H.; Nagasawa, T.; Mori, N. Varied B-cell immunophenotypes of Hodgkin/Reed-Sternberg cells in classic Hodgkin's disease. Histopathology 2000, 36, 353-361. [CrossRef] [PubMed]

13. Schwering, I.; Brauninger, A.; Klein, U.; Jungnickel, B.; Tinguely, M.; Diehl, V.; Hansmann, M.L.; Dalla-Favera, R.; Rajewsky, K.; Kuppers, R. Loss of the b-lineage-specific gene expression program in Hodgkin and Reed-Sternberg cells of Hodgkin lymphoma. Blood 2003, 101, 1505-1512. [CrossRef] [PubMed]

14. Stein, H.; Gerdes, J.; Kirchner, H.; Schaadt, M.; Diehl, V. Hodgkin and sternberg-reed cell antigen(s) detected by an antiserum to a cell line (1428) derived from Hodgkin's disease. Int. J. Cancer 1981, 28, 425-429. [CrossRef] [PubMed]

15. Stein, H.; Uchanska-Ziegler, B.; Gerdes, J.; Ziegler, A.; Wernet, P. Hodgkin and sternberg-reed cells contain antigens specific to late cells of granulopoiesis. Int. J. Cancer 1982, 29, 283-290. [CrossRef] [PubMed]

16. Hsu, S.M.; Jaffe, E.S. Leu M1 and peanut agglutinin stain the neoplastic cells of Hodgkin's disease. Am. J. Clin. Pathol. 1984, 82, 29-32. [CrossRef] [PubMed]

17. Stein, H.; Mason, D.Y.; Gerdes, J.; O'Connor, N.; Wainscoat, J.; Pallesen, G.; Gatter, K.; Falini, B.; Delsol, G.; Lemke, H.; et al. The expression of the Hodgkin's disease associated antigen KI-1 in reactive and neoplastic lymphoid tissue: Evidence that Reed-Sternberg cells and histiocytic malignancies are derived from activated lymphoid cells. Blood 1985, 66, 848-858. [PubMed] 
18. Schwarting, R.; Gerdes, J.; Durkop, H.; Falini, B.; Pileri, S.; Stein, H. BER-H2: A new anti-KI-1 (CD30) monoclonal antibody directed at a formol-resistant epitope. Blood 1989, 74, 1678-1689. [PubMed]

19. Von Wasielewski, R.; Mengel, M.; Fischer, R.; Hansmann, M.L.; Hubner, K.; Franklin, J.; Tesch, H.; Paulus, U.; Werner, M.; Diehl, V.; et al. Classical Hodgkin's disease. Clinical impact of the immunophenotype. Am. J. Pathol. 1997, 151, 1123-1130. [PubMed]

20. Pileri, S.A.; Ascani, S.; Leoncini, L.; Sabattini, E.; Zinzani, P.L.; Piccaluga, P.P.; Pileri, A., Jr.; Giunti, M.; Falini, B.; Bolis, G.B.; et al. Hodgkin's lymphoma: The pathologist's viewpoint. J. Clin. Pathol. 2002, 55, 162-176. [CrossRef] [PubMed]

21. Karnik, S.; Srinivasan, B.; Nair, S. Hodgkin's lymphoma: Immunohistochemical features and its association with EBV LMP-1. Experience from a south Indian hospital. Pathology 2003, 35, 207-211. [CrossRef] [PubMed]

22. Joos, S.; Kupper, M.; Ohl, S.; von Bonin, F.; Mechtersheimer, G.; Bentz, M.; Marynen, P.; Moller, P.; Pfreundschuh, M.; Trumper, L.; et al. Genomic imbalances including amplification of the tyrosine kinase gene JAK2 in CD30+ Hodgkin cells. Cancer Res. 2000, 60, 549-552. [PubMed]

23. Joos, S.; Menz, C.K.; Wrobel, G.; Siebert, R.; Gesk, S.; Ohl, S.; Mechtersheimer, G.; Trumper, L.; Moller, P.; Lichter, P.; et al. Classical Hodgkin lymphoma is characterized by recurrent copy number gains of the short arm of chromosome 2. Blood 2002, 99, 1381-1387. [CrossRef] [PubMed]

24. Jundt, F.; Acikgoz, O.; Kwon, S.H.; Schwarzer, R.; Anagnostopoulos, I.; Wiesner, B.; Mathas, S.; Hummel, M.; Stein, H.; Reichardt, H.M.; et al. Aberrant expression of notch1 interferes with the B-lymphoid phenotype of neoplastic b cells in classical Hodgkin lymphoma. Leukemia 2008, 22, 1587-1594. [CrossRef] [PubMed]

25. Bargou, R.C.; Emmerich, F.; Krappmann, D.; Bommert, K.; Mapara, M.Y.; Arnold, W.; Royer, H.D.; Grinstein, E.; Greiner, A.; Scheidereit, C.; et al. Constitutive nuclear factor-kappab-rela activation is required for proliferation and survival of Hodgkin's disease tumor cells. J. Clin. Investig. 1997, 100, 2961-2969. [CrossRef] [PubMed]

26. Martin-Subero, J.I.; Gesk, S.; Harder, L.; Sonoki, T.; Tucker, P.W.; Schlegelberger, B.; Grote, W.; Novo, F.J.; Calasanz, M.J.; Hansmann, M.L.; et al. Recurrent involvement of the REL and BCL11Aloci in classical Hodgkin lymphoma. Blood 2002, 99, 1474-1477. [CrossRef] [PubMed]

27. Barth, T.F.; Martin-Subero, J.I.; Joos, S.; Menz, C.K.; Hasel, C.; Mechtersheimer, G.; Parwaresch, R.M.; Lichter, P.; Siebert, R.; Mooller, P. Gains of $2 p$ involving the REL locus correlate with nuclear C-Rel protein accumulation in neoplastic cells of classical Hodgkin lymphoma. Blood 2003, 101, 3681-3686. [CrossRef] [PubMed]

28. Jost, P.J.; Ruland, J. Aberrant NF-kappab signaling in lymphoma: Mechanisms, consequences, and therapeutic implications. Blood 2007, 109, 2700-2707. [PubMed]

29. Mottok, A.; Steidl, C. Biology of classical Hodgkin lymphoma: Implications for prognosis and novel therapies. Blood 2018, 131, 1654-1665. [CrossRef] [PubMed]

30. Kube, D.; Holtick, U.; Vockerodt, M.; Ahmadi, T.; Haier, B.; Behrmann, I.; Heinrich, P.C.; Diehl, V.; Tesch, H. Stat3 is constitutively activated in Hodgkin cell lines. Blood 2001, 98, 762-770. [CrossRef] [PubMed]

31. Skinnider, B.F.; Elia, A.J.; Gascoyne, R.D.; Patterson, B.; Trumper, L.; Kapp, U.; Mak, T.W. Signal transducer and activator of transcription 6 is frequently activated in Hodgkin and Reed-Sternberg cells of Hodgkin lymphoma. Blood 2002, 99, 618-626. [CrossRef] [PubMed]

32. Scheeren, F.A.; Diehl, S.A.; Smit, L.A.; Beaumont, T.; Naspetti, M.; Bende, R.J.; Blom, B.; Karube, K.; Ohshima, K.; van Noesel, C.J.; et al. Il-21 is expressed in Hodgkin lymphoma and activates stat5: Evidence that activated stat5 is required for Hodgkin lymphomagenesis. Blood 2008, 111, 4706-4715. [CrossRef] [PubMed]

33. Tiacci, E.; Ladewig, E.; Schiavoni, G.; Penson, A.; Fortini, E.; Pettirossi, V.; Wang, Y.; Rosseto, A.; Venanzi, A.; Vlasevska, S.; et al. Pervasive mutations of jak-stat pathway genes in classical Hodgkin lymphoma. Blood 2018, 131, 2454-2465. [CrossRef] [PubMed]

34. Guffei, A.; Sarkar, R.; Klewes, L.; Righolt, C.; Knecht, H.; Mai, S. Dynamic chromosomal rearrangements in Hodgkin's lymphoma are due to ongoing three-dimensional nuclear remodeling and breakage-bridge-fusion cycles. Haematologica 2010, 95, 2038-2046. [CrossRef] [PubMed]

35. Knecht, H.; Johnson, N.A.; Haliotis, T.; Lichtensztejn, D.; Mai, S. Disruption of direct 3D telomere-TRF2 interaction through two molecularly disparate mechanisms is a hallmark of primary Hodgkin and Reed-Sternberg cells. Lab. Investig. 2017, 97, 772-781. [CrossRef] [PubMed] 
36. Re, D.; Kuppers, R.; Diehl, V. Molecular pathogenesis of Hodgkin's lymphoma. J. Clin. Oncol. 2005, 23, 6379-6386. [CrossRef] [PubMed]

37. Gandhi, M.K.; Lambley, E.; Duraiswamy, J.; Dua, U.; Smith, C.; Elliott, S.; Gill, D.; Marlton, P.; Seymour, J.; Khanna, R. Expression of LAG-3 by tumor-infiltrating lymphocytes is coincident with the suppression of latent membrane antigen-specific CD8+ T-cell function in Hodgkin lymphoma patients. Blood 2006, 108, 2280-2289. [CrossRef] [PubMed]

38. Vardhana, S.; Younes, A. The immune microenvironment in Hodgkin lymphoma: T cells, B cells, and immune checkpoints. Haematologica 2016, 101, 794-802. [CrossRef] [PubMed]

39. Van den Berg, A.; Visser, L.; Poppema, S. High expression of the cc chemokine TARC in Reed-Sternberg cells. A possible explanation for the characteristic t-cell infiltratein Hodgkin's lymphoma. Am. J. Pathol. 1999, 154, 1685-1691. [CrossRef]

40. Morris, C.S.; Stuart, A.E. Reed-Sternberg/lymphocyte rosette: Lymphocyte subpopulations as defined by monoclonal antibodies. J. Clin. Pathol. 1984, 37, 767-771. [CrossRef] [PubMed]

41. Carbone, A.; Gloghini, A.; Gattei, V.; Aldinucci, D.; Degan, M.; De Paoli, P.; Zagonel, V.; Pinto, A. Expression of functional CD40 antigen on Reed-Sternberg cells and Hodgkin's disease cell lines. Blood 1995, 85, 780-789. [PubMed]

42. Annunziata, C.M.; Safiran, Y.J.; Irving, S.G.; Kasid, U.N.; Cossman, J. Hodgkin disease: Pharmacologic intervention of the CD40-NF kappa b pathway by a protease inhibitor. Blood 2000, 96, 2841-2848. [PubMed]

43. Aldinucci, D.; Gloghini, A.; Pinto, A.; Colombatti, A.; Carbone, A. The role of CD40/CD40L and interferon regulatory factor 4 in Hodgkin lymphoma microenvironment. Leuk. Lymphoma 2012, 53, 195-201. [CrossRef] [PubMed]

44. Carey, C.D.; Connelly, C.; Gjini, E.; Roemer, M.G.; Stack, E.; Hodi, S.; Shipp, M.A.; Rodig, S.J. Quantitative assessment of PD-L1 expression in classical Hodgkin lymphoma suggests a critical role for tumor associated macrophages in suppressing anti-tumor immunity. Blood 2015, 126, 1440.

45. Gatalica, Z.; Bilalovic, N.; Vranic, S.; Arguello, D.; Reddy, S.; Ghosh, N. PD-L1 and PD1 expression in lymphomas. Blood 2015, 126, 3899.

46. Green, M.R.; Monti, S.; Rodig, S.J.; Juszczynski, P.; Currie, T.; O’Donnell, E.; Chapuy, B.; Takeyama, K.; Neuberg, D.; Golub, T.R.; et al. Integrative analysis reveals selective 9p24.1 amplification, increased PD-1 ligand expression, and further induction via JAK2 in nodular sclerosing Hodgkin lymphoma and primary mediastinal large b-cell lymphoma. Blood 2010, 116, 3268-3277. [CrossRef] [PubMed]

47. Chen, B.J.; Chapuy, B.; Ouyang, J.; Sun, H.H.; Roemer, M.G.; Xu, M.L.; Yu, H.; Fletcher, C.D.; Freeman, G.J.; Shipp, M.A.; et al. PD-L1 expression is characteristic of a subset of aggressive B-cell lymphomas and virus-associated malignancies. Clin. Cancer Res. 2013, 19, 3462-3473. [CrossRef] [PubMed]

48. Green, M.R.; Rodig, S.; Juszczynski, P.; Ouyang, J.; Sinha, P.; O’Donnell, E.; Neuberg, D.; Shipp, M.A. Constitutive AP-1 activity and EBV infection induce PD-L1 in Hodgkin lymphomas and posttransplant lymphoproliferative disorders: Implications for targeted therapy. Clin. Cancer Res. 2012, 18, 1611-1618. [CrossRef] [PubMed]

49. Gravelle, P.; Burroni, B.; Pericart, S.; Rossi, C.; Bezombes, C.; Tosolini, M.; Damotte, D.; Brousset, P.; Fournie, J.J.; Laurent, C. Mechanisms of PD-1/PD-L1 expression and prognostic relevance in non-Hodgkin lymphoma: A summary of immunohistochemical studies. Oncotarget 2017, 8, 44960-44975. [CrossRef] [PubMed]

50. Oudejans, J.J.; Jiwa, N.M.; Kummer, J.A.; Horstman, A.; Vos, W.; Baak, J.P.; Kluin, P.M.; van der Valk, P.; Walboomers, J.M.; Meijer, C.J. Analysis of major histocompatibility complex class I expression on Reed-Sternberg cells in relation to the cytotoxic T-cell response in epstein-barr virus-positive and -negative Hodgkin's disease. Blood 1996, 87, 3844-3851. [PubMed]

51. Reichel, J.; Chadburn, A.; Rubinstein, P.G.; Giulino-Roth, L.; Tam, W.; Liu, Y.; Gaiolla, R.; Eng, K.; Brody, J.; Inghirami, G.; et al. Flow sorting and exome sequencing reveal the oncogenome of primary Hodgkin and Reed-Sternberg cells. Blood 2015, 125, 1061-1072. [CrossRef] [PubMed]

52. Roemer, M.G.; Advani, R.H.; Redd, R.A.; Pinkus, G.S.; Natkunam, Y.; Ligon, A.H.; Connelly, C.F.; Pak, C.J.; Carey, C.D.; Daadi, S.E.; et al. Classical Hodgkin lymphoma with reduced beta2M/MHC class I expression is associated with inferior outcome independent of 9p24.1 status. Cancer Immunol. Res. 2016, 4, 910-916. [CrossRef] [PubMed] 
53. Diepstra, A.; van Imhoff, G.W.; Karim-Kos, H.E.; van den Berg, A.; te Meerman, G.J.; Niens, M.; Nolte, I.M.; Bastiaannet, E.; Schaapveld, M.; Vellenga, E.; et al. Hla class ii expression by Hodgkin Reed-Sternberg cells is an independent prognostic factor in classical Hodgkin's lymphoma. J. Clin. Oncol. 2007, 25, 3101-3108. [CrossRef] [PubMed]

54. Barrington, S.F.; Mikhaeel, N.G.; Kostakoglu, L.; Meignan, M.; Hutchings, M.; Mueller, S.P.; Schwartz, L.H.; Zucca, E.; Fisher, R.I.; Trotman, J.; et al. Role of imaging in the staging and response assessment of lymphoma: Consensus of the international conference on malignant lymphomas imaging working group. J. Clin. Oncol. 2014, 32, 3048-3058. [CrossRef] [PubMed]

55. Skoetz, N.; Will, A.; Monsef, I.; Brillant, C.; Engert, A.; von Tresckow, B. Comparison of first-line chemotherapy including escalated BEACOPP versus chemotherapy including ABVD for people with early unfavourable or advanced stage Hodgkin lymphoma. Cochrane Database Syst. Rev. 2017, 5, CD007941. [CrossRef] [PubMed]

56. Brockelmann, P.J.; Sasse, S.; Engert, A. Balancing risk and benefit in early-stage classical Hodgkin lymphoma. Blood 2018, 131, 1666-1678. [CrossRef] [PubMed]

57. Lim, S.H.; Johnson, P.W.M. Optimizing therapy in advanced stage Hodgkin lymphoma. Blood 2018, 131, 1679-1688. [CrossRef] [PubMed]

58. Engert, A.; Plutschow, A.; Eich, H.T.; Lohri, A.; Dorken, B.; Borchmann, P.; Berger, B.; Greil, R.; Willborn, K.C.; Wilhelm, M.; et al. Reduced treatment intensity in patients with early-stage Hodgkin's lymphoma. N. Engl. J. Med. 2010, 363, 640-652. [CrossRef] [PubMed]

59. Von Tresckow, B.; Plutschow, A.; Fuchs, M.; Klimm, B.; Markova, J.; Lohri, A.; Kral, Z.; Greil, R.; Topp, M.S.; Meissner, J.; et al. Dose-intensification in early unfavorable Hodgkin's lymphoma: Final analysis of the german Hodgkin study group hd14 trial. J. Clin. Oncol. 2012, 30, 907-913. [CrossRef] [PubMed]

60. Meyer, R.M.; Gospodarowicz, M.K.; Connors, J.M.; Pearcey, R.G.; Wells, W.A.; Winter, J.N.; Horning, S.J.; Dar, A.R.; Shustik, C.; Stewart, D.A.; et al. ABVD alone versus radiation-based therapy in limited-stage Hodgkin's lymphoma. N. Engl. J. Med. 2012, 366, 399-408. [CrossRef] [PubMed]

61. Radford, J.; Illidge, T.; Counsell, N.; Hancock, B.; Pettengell, R.; Johnson, P.; Wimperis, J.; Culligan, D.; Popova, B.; Smith, P.; et al. Results of a trial of pet-directed therapy for early-stage Hodgkin's lymphoma. N. Engl. J. Med. 2015, 372, 1598-1607. [CrossRef] [PubMed]

62. Andre, M.P.E.; Girinsky, T.; Federico, M.; Reman, O.; Fortpied, C.; Gotti, M.; Casasnovas, O.; Brice, P.; van der Maazen, R.; Re, A.; et al. Early positron emission tomography response-adapted treatment in stage I and II Hodgkin lymphoma: Final results of the randomized EORTC/LYSA/FIL H10 trial. J. Clin. Oncol. 2017, 35, 1786-1794. [CrossRef] [PubMed]

63. Viviani, S.; Zinzani, P.L.; Rambaldi, A.; Brusamolino, E.; Levis, A.; Bonfante, V.; Vitolo, U.; Pulsoni, A.; Liberati, A.M.; Specchia, G.; et al. ABVD versus beacopp for Hodgkin's lymphoma when high-dose salvage is planned. N. Engl. J. Med. 2011, 365, 203-212. [CrossRef] [PubMed]

64. Johnson, P.; Federico, M.; Kirkwood, A.; Fossa, A.; Berkahn, L.; Carella, A.; d'Amore, F.; Enblad, G.; Franceschetto, A.; Fulham, M.; et al. Adapted treatment guided by interim PET-CT scan in advanced Hodgkin's lymphoma. N. Engl. J. Med. 2016, 374, 2419-2429. [CrossRef] [PubMed]

65. Connors, J.M.; Jurczak, W.; Straus, D.J.; Ansell, S.M.; Kim, W.S.; Gallamini, A.; Younes, A.; Alekseev, S.; Illes, A.; Picardi, M.; et al. Brentuximab vedotin with chemotherapy for stage III or IV Hodgkin's lymphoma. N. Engl. J. Med. 2018, 378, 331-344. [CrossRef] [PubMed]

66. Schmitz, N.; Pfistner, B.; Sextro, M.; Sieber, M.; Carella, A.M.; Haenel, M.; Boissevain, F.; Zschaber, R.; Muller, P.; Kirchner, H.; et al. Aggressive conventional chemotherapy compared with high-dose chemotherapy with autologous haemopoietic stem-cell transplantation for relapsed chemosensitive Hodgkin's disease: A randomised trial. Lancet 2002, 359, 2065-2071. [CrossRef]

67. Nikolaenko, L.; Chen, R.; Herrera, A.F. Current strategies for salvage treatment for relapsed classical Hodgkin lymphoma. Ther. Adv. Hematol. 2017, 8, 293-302. [CrossRef] [PubMed]

68. Reece, D.E.; Barnett, M.J.; Shepherd, J.D.; Hogge, D.E.; Klasa, R.J.; Nantel, S.H.; Sutherland, H.J.; Klingemann, H.G.; Fairey, R.N.; Voss, N.J.; et al. High-dose cyclophosphamide, carmustine (BCNU), and etoposide (VP16-213) with or without cisplatin $(\mathrm{CBV}+/-\mathrm{p})$ and autologous transplantation for patients with Hodgkin's disease who fail to enter a complete remission after combination chemotherapy. Blood 1995, 86, 451-456. [PubMed] 
69. Andre, M.; Henry-Amar, M.; Pico, J.L.; Brice, P.; Blaise, D.; Kuentz, M.; Coiffier, B.; Colombat, P.; Cahn, J.Y.; Attal, M.; et al. Comparison of high-dose therapy and autologous stem-cell transplantation with conventional therapy for Hodgkin's disease induction failure: A case-control study. Societe francaise de greffe de moelle. J. Clin. Oncol. 1999, 17, 222-229. [CrossRef] [PubMed]

70. Majhail, N.S.; Weisdorf, D.J.; Defor, T.E.; Miller, J.S.; McGlave, P.B.; Slungaard, A.; Arora, M.; Ramsay, N.K.; Orchard, P.J.; MacMillan, M.L.; et al. Long-term results of autologous stem cell transplantation for primary refractory or relapsed Hodgkin's lymphoma. Biol. Blood Marrow Transplant. 2006, 12, 1065-1072. [CrossRef] [PubMed]

71. Forero-Torres, A.; Leonard, J.P.; Younes, A.; Rosenblatt, J.D.; Brice, P.; Bartlett, N.L.; Bosly, A.; Pinter-Brown, L.; Kennedy, D.; Sievers, E.L.; et al. A phase ii study of SGN-30 (anti-CD30 mAb) in Hodgkin lymphoma or systemic anaplastic large cell lymphoma. Br. J. Haematol. 2009, 146, 171-179. [CrossRef] [PubMed]

72. Younes, A.; Gopal, A.K.; Smith, S.E.; Ansell, S.M.; Rosenblatt, J.D.; Savage, K.J.; Ramchandren, R.; Bartlett, N.L.; Cheson, B.D.; de Vos, S.; et al. Results of a pivotal phase II study of brentuximab vedotin for patients with relapsed or refractory Hodgkin's lymphoma. J. Clin. Oncol. 2012, 30, 2183-2189. [CrossRef] [PubMed]

73. Chen, R.; Gopal, A.K.; Smith, S.E.; Ansell, S.M.; Rosenblatt, J.D.; Savage, K.J.; Connors, J.M.; Engert, A.; Larsen, E.K.; Huebner, D.; et al. Five-year survival and durability results of brentuximab vedotin in patients with relapsed or refractory Hodgkin lymphoma. Blood 2016, 128, 1562-1566. [CrossRef] [PubMed]

74. O'Connor, O.A.; Lue, J.K.; Sawas, A.; Amengual, J.E.; Deng, C.; Kalac, M.; Falchi, L.; Marchi, E.; Turenne, I.; Lichtenstein, R.; et al. Brentuximab vedotin plus bendamustine in relapsed or refractory Hodgkin's lymphoma: An international, multicentre, single-arm, phase 1-2 trial. Lancet Oncol. 2018, 19, 257-266. [CrossRef]

75. LaCasce, A.S.; Bociek, R.G.; Sawas, A.; Caimi, P.; Agura, E.; Matous, J.; Ansell, S.M.; Crosswell, H.E.; Islas-Ohlmayer, M.; Behler, C.; et al. Brentuximab vedotin plus bendamustine: A highly active first salvage regimen for relapsed or refractory Hodgkin lymphoma. Blood 2018. [CrossRef] [PubMed]

76. Moskowitz, C.H.; Nademanee, A.; Masszi, T.; Agura, E.; Holowiecki, J.; Abidi, M.H.; Chen, A.I.; Stiff, P.; Gianni, A.M.; Carella, A.; et al. Brentuximab vedotin as consolidation therapy after autologous stem-cell transplantation in patients with Hodgkin's lymphoma at risk of relapse or progression (AETHERA): A randomised, double-blind, placebo-controlled, phase 3 trial. Lancet 2015, 385, 1853-1862. [CrossRef]

77. Pardoll, D.M. The blockade of immune checkpoints in cancer immunotherapy. Nat. Rev. Cancer 2012, 12, 252-264. [CrossRef] [PubMed]

78. Jiang, Y.; Li, Y.; Zhu, B. T-cell exhaustion in the tumor microenvironment. Cell Death Dis. 2015, 6, e1792. [CrossRef] [PubMed]

79. Odorizzi, P.M.; Wherry, E.J. Inhibitory receptors on lymphocytes: Insights from infections. J. Immunol. 2012, 188, 2957-2965. [CrossRef] [PubMed]

80. Yamamoto, R.; Nishikori, M.; Kitawaki, T.; Sakai, T.; Hishizawa, M.; Tashima, M.; Kondo, T.; Ohmori, K.; Kurata, M.; Hayashi, T.; et al. PD-1-PD-1 ligand interaction contributes to immunosuppressive microenvironment of Hodgkin lymphoma. Blood 2008, 111, 3220-3224. [CrossRef] [PubMed]

81. Blackburn, S.D.; Shin, H.; Haining, W.N.; Zou, T.; Workman, C.J.; Polley, A.; Betts, M.R.; Freeman, G.J.; Vignali, D.A.; Wherry, E.J. Coregulation of CD8+ $\mathrm{t}$ cell exhaustion by multiple inhibitory receptors during chronic viral infection. Nat. Immunol. 2009, 10, 29-37. [CrossRef] [PubMed]

82. Hodi, F.S.; O’Day, S.J.; McDermott, D.F.; Weber, R.W.; Sosman, J.A.; Haanen, J.B.; Gonzalez, R.; Robert, C.; Schadendorf, D.; Hassel, J.C.; et al. Improved survival with ipilimumab in patients with metastatic melanoma. N. Engl. J. Med. 2010, 363, 711-723. [CrossRef] [PubMed]

83. Postow, M.A.; Callahan, M.K.; Wolchok, J.D. Immune checkpoint blockade in cancer therapy. J. Clin. Oncol. 2015, 33, 1974-1982. [CrossRef] [PubMed]

84. Barber, D.L.; Wherry, E.J.; Masopust, D.; Zhu, B.; Allison, J.P.; Sharpe, A.H.; Freeman, G.J.; Ahmed, R. Restoring function in exhausted CD8 T cells during chronic viral infection. Nature 2006, 439, 682-687. [CrossRef] [PubMed]

85. Nguyen, L.T.; Ohashi, P.S. Clinical blockade of PD1 and LAG3-potential mechanisms of action. Nat. Rev. Immunol. 2015, 15, 45-56. [CrossRef] [PubMed] 
86. Ansell, S.M.; Lesokhin, A.M.; Borrello, I.; Halwani, A.; Scott, E.C.; Gutierrez, M.; Schuster, S.J.; Millenson, M.M.; Cattry, D.; Freeman, G.J.; et al. PD-1 blockade with nivolumab in relapsed or refractory Hodgkin's lymphoma. N. Engl. J. Med. 2015, 372, 311-319. [CrossRef] [PubMed]

87. Armand, P.; Shipp, M.A.; Ribrag, V.; Michot, J.M.; Zinzani, P.L.; Kuruvilla, J.; Snyder, E.S.; Ricart, A.D.; Balakumaran, A.; Rose, S.; et al. Programmed death-1 blockade with pembrolizumab in patients with classical Hodgkin lymphoma after brentuximab vedotin failure. J. Clin. Oncol. 2016, 34, 3733-3739. [CrossRef] [PubMed]

88. Chen, R.; Zinzani, P.L.; Fanale, M.A.; Armand, P.; Johnson, N.A.; Brice, P.; Radford, J.; Ribrag, V.; Molin, D.; Vassilakopoulos, T.P.; et al. Phase II study of the efficacy and safety of pembrolizumab for relapsed/refractory classic Hodgkin lymphoma. J. Clin. Oncol. 2017, 35, 2125-2132. [CrossRef] [PubMed]

89. Moskowitz, C.H.; Chen, R.W.; Armand, P.; Zinzani, P.L.; Vassilakopoulos, T.P.; Goldmacher, G.V.; Lin, J.; Nahar, A.; Balakumaran, A.; Salles, G. Pembrolizumab antitumor activity in relapsed/refractory classical Hodgkin lymphoma in keynote-087: Revised response criteria for malignant lymphoma 2007 criteria versus lugano 2014 classification. Blood 2017, 130, 4085.

90. Armand, P.; Engert, A.; Younes, A.; Fanale, M.; Santoro, A.; Zinzani, P.L.; Timmerman, J.M.; Collins, G.P.; Ramchandren, R.; Cohen, J.B.; et al. Nivolumab for relapsed/refractory classic Hodgkin lymphoma after failure of autologous hematopoietic cell transplantation: Extended follow-up of the multicohort single-arm phase II checkmate 205 trial. J. Clin. Oncol. 2018, 36, 1428-1439. [CrossRef] [PubMed]

91. Chen, R.; Gibb, A.L.; Collins, G.P.; Popat, R.; El-Sharkawi, D.; Burton, C.; Lewis, D.; Miall, F.M.; Forgie, A.; Compagnoni, A.; et al. Blockade of the PD-1 checkpoint with anti-PD-L1 antibody avelumab is sufficienct for clinical activity in relapsed/refractory classical Hodgkin lymphoma (CHL). Hematol. Oncol. 2017, 35, 67. [CrossRef]

92. Younes, A.; Santoro, A.; Shipp, M.; Zinzani, P.L.; Timmerman, J.M.; Ansell, S.; Armand, P.; Fanale, M.; Ratanatharathorn, V.; Kuruvilla, J.; et al. Nivolumab for classical Hodgkin's lymphoma after failure of both autologous stem-cell transplantation and brentuximab vedotin: A multicentre, multicohort, single-arm phase 2 trial. Lancet Oncol. 2016, 17, 1283-1294. [CrossRef]

93. Ansell, S.; Gutierrez, M.E.; Shipp, M.A.; Gladstone, D.; Moskowitz, A.; Borello, I.; Popa-Mckiver, M.; Farsaci, B.; Zhu, L.; Lesokhin, A.M.; et al. A phase 1 study of nivolumab in combination with ipilimumab for relapsed or refractory hematologic malignancies (checkmate 039). Blood 2016, 128, 183.

94. Herrera, A.F.; Moskowitz, A.J.; Bartlett, N.L.; Vose, J.M.; Ramchandren, R.; Feldman, T.A.; LaCasce, A.S.; Ansell, S.M.; Moskowitz, C.H.; Fenton, K.; et al. Interim results of brentuximab vedotin in combination with nivolumab in patients with relapsed or refractory Hodgkin lymphoma. Blood 2018, 131, 1183-1194. [CrossRef] [PubMed]

95. Diefenbach, C.S.; Hong, F.; Cohen, J.B.; Robertson, M.J.; Ambinder, R.F.; Fenske, T.S.; Advani, R.H.; Kahl, B.S.; Ansell, S. Preliminary safety and efficacy of the combination of brentuximab vedotin and ipilimumab in relapsed/refractory Hodgkin lymphoma: A trial of the ECOG-ACRIN cancer research group (E4412). Blood 2015, 126, 585.

96. Ramchandren, R. Nivolumab for newly diagnosed advanced-stage classical Hodgkin lymphoma (CHL): Results from the phase 2 checkmate 205 study. In Proceedings of the 59th Annual American Society of Hematology Conference, San Diego, CA, USA, 6 December 2017.

97. Diefenbach, C.S.; Hong, F.; David, K.; Cohen, J.; Roberston, M.; Advani, R.; Palmisano, N.; Ambinder, R.; Kahl, B.; Ansell, S. Safety and efficacy of combination of brentuximab vedotin and nivolumab in relapsed/refractory Hodgkin lymphoma: A trial of the ecog-acrin cancer research group (e4412). Hematol. Oncol. 2017, 35, 84-85. [CrossRef]

98. Cheson, B.D.; Pfistner, B.; Juweid, M.E.; Gascoyne, R.D.; Specht, L.; Horning, S.J.; Coiffier, B.; Fisher, R.I.; Hagenbeek, A.; Zucca, E.; et al. Revised response criteria for malignant lymphoma. J. Clin. Oncol. 2007, 25, 579-586. [CrossRef] [PubMed]

99. Cheson, B.D.; Fisher, R.I.; Barrington, S.F.; Cavalli, F.; Schwartz, L.H.; Zucca, E.; Lister, T.A.; Alliance, A.L.; Lymphoma, G.; Eastern Cooperative Oncology, G.; et al. Recommendations for initial evaluation, staging, and response assessment of Hodgkin and non-Hodgkin lymphoma: The lugano classification. J. Clin. Oncol. 2014, 32, 3059-3068. [CrossRef] [PubMed] 
100. Cheson, B.D.; Ansell, S.; Schwartz, L.; Gordon, L.I.; Advani, R.; Jacene, H.A.; Hoos, A.; Barrington, S.F.; Armand, P. Refinement of the lugano classification lymphoma response criteria in the era of immunomodulatory therapy. Blood 2016, 128, 2489-2496. [CrossRef] [PubMed]

101. Gandhi, L.; Rodriguez-Abreu, D.; Gadgeel, S.; Esteban, E.; Felip, E.; De Angelis, F.; Domine, M.; Clingan, P.; Hochmair, M.J.; Powell, S.F.; et al. Pembrolizumab plus chemotherapy in metastatic non-small-cell lung cancer. N. Engl. J. Med. 2018, 378, 2078-2092. [CrossRef] [PubMed]

102. Zinzani, P.L.; Fanale, M.A.; Chen, R.; Armand, P.; Johnson, N.; Brice, P.; Radford, J.; Ribrag, V.; Molin, D.; Vassilakopoulos, T.P.; et al. Pembrolizumab monotherapy in patients with primary refractory classical Hodgkin lymphoma: Subgroup analysis of the phase 2 keynote-087 study [abstract 126]. In Proceedings of the 14th International Conference on Malignant Lymphoma, Lugano, Switzerland, 14-17 June 2017.

103. Tumeh, P.C.; Harview, C.L.; Yearley, J.H.; Shintaku, I.P.; Taylor, E.J.; Robert, L.; Chmielowski, B.; Spasic, M.; Henry, G.; Ciobanu, V.; et al. PD-1 blockade induces responses by inhibiting adaptive immune resistance. Nature 2014, 515, 568-571. [CrossRef] [PubMed]

104. Yarchoan, M.; Hopkins, A.; Jaffee, E.M. Tumor mutational burden and response rate to pd-1 inhibition. N. Engl. J. Med. 2017, 377, 2500-2501. [CrossRef] [PubMed]

105. Roemer, M.G.; Advani, R.H.; Ligon, A.H.; Natkunam, Y.; Redd, R.A.; Homer, H.; Connelly, C.F.; Sun, H.H.; Daadi, S.E.; Freeman, G.J.; et al. PD-L1 and PD-L2 genetic alterations define classical Hodgkin lymphoma and predict outcome. J. Clin. Oncol. 2016, 34, 2690-2697. [CrossRef] [PubMed]

106. Hude, I.; Sasse, S.; Brockelmann, P.J.; von Tresckow, B.; Momotow, J.; Engert, A.; Borchmann, S. Leucocyte and eosinophil counts predict progression-free survival in relapsed or refractory classical Hodgkin lymphoma patients treated with PD1 inhibition. Br. J. Haematol. 2017. [CrossRef] [PubMed]

107. Roemer, M.G.M.; Redd, R.A.; Cader, F.Z.; Pak, C.J.; Abdelrahman, S.; Ouyang, J.; Sasse, S.; Younes, A.; Fanale, M.; Santoro, A.; et al. Major histocompatibility complex class II and programmed death ligand 1 expression predict outcome after programmed death 1 blockade in classic Hodgkin lymphoma. J. Clin. Oncol. 2018, 36, 942-950. [CrossRef] [PubMed]

108. Manson, G.; Herbaux, C.; Brice, P.; Bouabdallah, K.; Stamatoullas, A.; Schiano, J.M.; Ghesquieres, H.; Dercle, L.; Houot, R. Prolonged remissions after anti-PD1 discontinuation in patients with Hodgkin lymphoma. Blood 2018. [CrossRef] [PubMed]

109. Evens, A.M.; Helenowski, I.; Ramsdale, E.; Nabhan, C.; Karmali, R.; Hanson, B.; Parsons, B.; Smith, S.; Larsen, A.; McKoy, J.M.; et al. A retrospective multicenter analysis of elderly Hodgkin lymphoma: Outcomes and prognostic factors in the modern era. Blood 2012, 119, 692-695. [CrossRef] [PubMed]

110. Thyss, A.; Saada, E.; Gastaud, L.; Peyrade, F.; Re, D. Hodgkin's lymphoma in older patients: An orphan disease? Mediterr. J. Hematol. Infect. Dis. 2014, 6, e2014050. [CrossRef] [PubMed]

111. Allen, P.B.; Gordon, L.I. Frontline therapy for classical Hodgkin lymphoma by stage and prognostic factors. Clin. Med. Insights Oncol. 2017, 11, 1179554917731072. [CrossRef] [PubMed]

112. Derer, A.; Frey, B.; Fietkau, R.; Gaipl, U.S. Immune-modulating properties of ionizing radiation: Rationale for the treatment of cancer by combination radiotherapy and immune checkpoint inhibitors. Cancer Immunol. Immunother. 2016, 65, 779-786. [CrossRef] [PubMed]

113. Postow, M.A.; Callahan, M.K.; Barker, C.A.; Yamada, Y.; Yuan, J.; Kitano, S.; Mu, Z.; Rasalan, T.; Adamow, M.; Ritter, E.; et al. Immunologic correlates of the abscopal effect in a patient with melanoma. N. Engl. J. Med. 2012, 366, 925-931. [CrossRef] [PubMed]

114. Ngwa, W.; Irabor, O.C.; Schoenfeld, J.D.; Hesser, J.; Demaria, S.; Formenti, S.C. Using immunotherapy to boost the abscopal effect. Nat. Rev. Cancer 2018, 18, 313-322. [CrossRef] [PubMed]

115. Brockelmann, P.J.; Engert, A. Checkpoint inhibition in Hodgkin lymphoma-A review. Oncol. Res. Treat. 2017, 40, 654-660. [CrossRef] [PubMed]

116. Spina, V.; Bruscaggin, A.; Cuccaro, A.; Martini, M.; Di Trani, M.; Forestieri, G.; Manzoni, M.; Condoluci, A.; Arribas, A.; Terzi-Di-Bergamo, L.; et al. Circulating tumor DNA reveals genetics, clonal evolution and residual disease in classical Hodgkin lymphoma. Blood 2018, 131, 2413-2425. [CrossRef] [PubMed]

(C) 2018 by the authors. Licensee MDPI, Basel, Switzerland. This article is an open access article distributed under the terms and conditions of the Creative Commons Attribution (CC BY) license (http:/ / creativecommons.org/licenses/by/4.0/). 